\title{
Luhmann and the media
}

\section{Jesper Tække \& Michael Paulsen}

MedieKultur 2010, 49, 1-10

Published by SMID | Society of Media researchers In Denmark | www.smid.dk The online version of this text can be found open access at www.mediekultur.dk

Welcome to MedieKultur! This special issue is dedicated to the media theory of German sociologist and systems theorist Niklas Luhmann. We begin this introduction with an overview of his theory and end it with a brief presentation of the articles included in this issue, which utilise the theory in many different ways, and try to use it to conceptualise and understand many different phenomena, from Facebook to artificial intelligence.

\section{Introduction}

Luhmann (1995, p. 271, 1999, p. 201) describes social systems as systems that reproduce themselves in the medium of communication. Because social systems maintain themselves in the medium of communication, they are separate from everything that does not communicate (Luhmann, 2000b, p. 10). Unlike in medium theory (McLuhan, 1967; Ong, 1982; Eisenstein, 1983; Meyrowitz, 1985), media are not seen as mechanisms for transmission. This is because Luhmann is a systems theorist, doing communication sociology, inspired by Bateson (2000; communication is a non-linearly process), von Foerster (1981; systems create their own outlook and in this regard construct their outer world) and Maturana (1980; systems are operationally closed). The result is that the concept of medium becomes cardinal in Luhmann's theoretical architecture, describing how communication functions when it is not a transmission process between psychic systems, but a medium of social reality per se. In this short introduction, we first briefly discuss communication and thereafter 
point out some essential concepts and coherences in Luhmann's medium theory, and end with linking the articles in the journal in relation to these headlines.

\section{Communication as a medium}

According to Luhmann, communication occurs when someone understands that something (and not something else) is uttered in one mode (and not in another) by someone else. This implies that all communication "requires a synthesis of three selections, namely information, utterance and understanding (including misunderstanding)" (Luhmann, 1990, p. 3). Information is the what of the communication, understood by Luhmann as the difference between what is actually uttered and other possible meanings. Utterance is the how and the why of the communication, which according to Luhmann is the difference between the particular mode of the communication and other possible modes. Finally, understanding is how someone other than the person making the informative utterance understands, that is, relates to the utterance in a new utterance (Luhmann, 1995, p. 140). The decisive factor is this last "recursive" selection, because it implies that communication cannot be directed or even established by one person (understanding is always someone else's understanding). A communicative operation only comes into being with the understanding (ibid.). This also implies that a communication only becomes part of a communication system if a new communication links to it, either accepting its proposal of meaning or negating it. Such linkages (following one another) produce a system with a history of accepted and negated proposals of meaning, differentiating the system from other social systems with other communication histories (Luhmann, 1995).

The upshot is that communication by definition never happens as an isolated element, but only in linkage with other communications. Social reality understood as social systems is mediated by different sequences of communicative selections. This means that selected unities of information, utterances and understandings are the medium of social reality, the "basic materiality", so to speak. Combining information, utterance and understanding in different ways and in different sequences based on different criteria brings about different social systems. This is very similar to how different molecules are realised through different combinations of atoms.

\section{The improbable communication and the mediated society}

Luhmann (1995, p. 158, 1990, p. 87) argues that it is improbable for the psychic systems to understand each other insofar as they are closed (as a psychic system, I do not communicate, but only think and perceive what I think and perceive). Further, it is improbable that communicative exchanges will occur among people who are not physically close to each other. And finally, the third improbability is success. Even if a communication is understood by the person it reaches, this does not guarantee that it is also accepted and followed. These 
three improbabilities make communication itself improbable. At this point, different kinds of specific media (of communication) enter systems theory as mechanisms which have evolved and have made communication probable. Luhmann (1995, p. 160-161, 1999) distinguishes between three different types of media, namely language, the medium that makes understanding probable, distribution media, such as writing and printing, which make it probable that messages reach receivers, and symbolically generalised communication media (money, power, laws etc.) that make it probable messages will have an effect (economical effect, political effect, legal effect etc.).

Luhmann argues that the functional systems of modern society, such as the legal, political, and economic systems, only have become probable due to the evolution of the symbolically generalised communication media. The legal system is, for instance, bounded and mediated by the medium of laws, the political system by the medium of power relations and the economic system by the medium of money. Without the emergence of these symbolic media, there would be no legal, political or economic systems. The media represent conditions for the possibility of modern society.

\section{Form and medium - an outstanding double concept}

Luhmann (1999, 2000a, 2002a) presents a completely abstract concept of media, based on the distinction between form and medium (Brauns, 2002). A form is defined by Luhmann as a tight coupling of elements within a medium of loosely coupled elements. According to Luhmann, there are only forms within a medium, and media only exist as such because of forms (Luhmann, 1999, 2000a; with inspiration from Heider, 1959, and Spencer-Brown, 1969). One example is a footprint in the sand on the beach. The sand consists of loosely coupled elements (small stones) that are structured by something more solid that has been imprinted on it, the foot. The sand becomes a medium because of the form imprinted on it, and the footprint as a form exists only because of the sand as medium. Through one imprinting foot, the sand elements are momentarily tightly coupled in one way. Through another they become fixed differently. Only because the sand elements are so loosely coupled relative to the imprinting foot (the small stones do not fuse together into a solid mass for instance, making it impossible for normal human feet to alter the coupling of the small stones), they are able to function as an effective medium of indefinitely many discrete footprints. Another similar example is language, which is the medium (consisting of loosely coupled phonemes) for the forms of words (tightly coupled phonemes). Without language there would be no words, and without words there would be no (advanced) language (Esposito, 1999). According to Krämer (1998), this double concept of form and medium is outstanding, at least compared to the Western philosophical tradition, in which the main trend from Plato and onwards has been to regard forms as the unalterable ground and fix point of all change and flux. With Luhmann's medium theory, forms become concep- 
tualised as something rather fugitive, eventual and fluid, while media are apprehended as relatively more stable, yet with evolutionary outcomes.

\section{Luhmann's three types of media}

In language, the medium of understanding, the operational forms are words and sentences. In distribution media, the operational forms are, among other things, printed texts. In symbolically generalized communication media, the forms are payments, scientific theories, etc. The three types of media function together. One can for instance receive a printed text with sentences saying that one has to pay the rent. This is only possible because the media of communication only create a weak substratum: language does not speak; the printing press does not decide what is written in the books; and in the scientific medium, truth produce no knowledge.

\section{The medium of understanding: language}

In spoken language, the distinction between form and medium is implied in the difference between meaning and sound (Luhmann, 1999, p. 231). This provides language with a special economy, which gives society a medium substratum with an unlimited number of possibilities for formations (Esposito 1999). Only with the medium of language can society become a self-referential system, because language makes it possible to communicate about communication (Luhmann, 1995, p. 153, 1999, p. 250). Without language there is no society. Language is "society's muse" (Luhmann, 1999, p. 225). Language does not achieve this role by having a built-in telos, as we see in the work of Habermas (1997, p. 211), but because it allows negations (Luhmann, 1999, p. 229). Every time a new form is printed into the medium of language, the medium is changed and society with it. As long as we only had spoken language, from an evolutionary perspective, it was not possible to differentiate between interaction and society.

\section{The media of distribution: from writing to digital media}

In the optical medium of writing, the distinction between form and medium is implied in the difference between meaning and combinations of letters (Luhmann, 1999, p. 256). This distinction makes it possible to de-couple communication from present time and space, extending society in time and space. Societal semantics and utterances are from now on "transportable" across local and limited time and space. With writing, it becomes possible to differentiate between interaction and society, opening for much more complex social formations by providing a stronger differentiation between object orientation and social orientation, i.e., to not take interaction partners into consideration when writing. This is a slow process in which the alphabetisation marks a specific threshold, because it enables 
rapid learning and with it universal dissemination, and differentiates regional languages from one another, and thus forces translation (Luhmann, 1995, p. 87, note 62). The printing press magnifies the social effects of writing and alphabetisation, and also means that the improbability of success in regard to the effect of communication is radicalised. Further, electronic media and the computer are media of distribution in Luhmann's theory. For Luhmann, such media abolish space and time as limits for communication. With computernetworks, it also becomes possible to share texts, and thus spatial distances, and because of this, we now see fields like medicine only distinguished thematically and not spatially, i.e., providing one global differentiation in the fact dimension (1999, p. 304).

\section{The media of effects: symbolically generalised communication media}

According to Luhmann, symbolically generalised communication media increase the probability of communicative effect. Prominent examples are money, which increases the probability of economical effects, power, which increases the probability of political effects, and law, which increases the probability of legal effects. These media all share basic characteristics. First of all, they pursue a general and symbolic code. The code of money is paying/not paying. The code of power is being in position/being in opposition. And the code of law is right/not right. The asymmetry within these binary codes is of a special kind. The left side always pertains to a positive value - everyone wants to be in a position of power, to be able to pay and to have the right to do what they do. The other side of the code always pertains to a negative or reflective value. No one wants to end up in a marginalised (op)position without power, without the possibility of paying for anything and without any legal rights. The negative value of the codes makes you think - that is reflect - how you can change your position, make money and achieve rights. The upshot is that societal communications that function and disseminate through such codes motivate participants to connect to the left sides of the codes and thereby accept the communication and thereby reproduce the society. The media make probable that communication is successful and in that way also ensure the formation of social systems (Luhmann, 1986, p. 18). Yet, communication does not always succeed. The codes only motivate and increase the probability. They do not determine the communicative reactions and effects.

The forms in these types of media are prizes, votes or court judgments (Luhmann, 1999, p. 320). By being coded in binary form, they separate out other communications. In science, for instance, only what is symbolised and generalised as possible true theory (truth being the medium of science and theories its forms) is acceptable as a scientific contribution. Together this implies, according to Luhmann, that nowadays we live in a functionally differentiated society. One of the most important results of this is that each "sphere" - i.e., economy, politics, science, etc. - functions operationally in a self-referential way. Political power, for instance, cannot be ensured by scientific truth or visa versa. Each functional system has its own criteria of success, its own medium and its own forms. In modern society, the 
probability of functional effects within each system are increased, but side effects across the systems become less likely. Somewhat thought-provokingly, Luhmann (2002b) argues, for instance, that political reforms of the system of education do not really alter the system of education. At best, or at worst, they only alter particular conditions within the system of education; for example, changing curricular programmes or adjusting the balance between general and specific aims.

\section{The mass media}

To give an example that is of particular interest in this special journal issue, let us briefly pay heed to the functional system of the Mass Media. The symbolically generalised communication medium of this system is information relying on the code information/not information. The Mass Media is separated out by the distribution medium, which both enables distribution and disables interaction between media organisations and their readers, listeners and viewers (Luhmann 2002b, p. 2). In this situation, the media organisations themselves must decide what has information value, which means that news criteria differ from organisation to organisation; or in other words, by having developed their own programmes for handling the code, they select differently in regard to what is thought to have information value. The process of this communication suggests that the positive values are constantly turned into the negative values; you cannot write the same thing - as a piece of information - in the paper two days in a row. At the same time, this process creates a history of communication in regard to which new happenings become information. If organisations or persons from the perspective of one of the other functional systems wants to have something known in public, they must tolerate the forms of the different mass media organisations and their different programmes for handling the code of information (Luhmann, 2000b). A politician, for instance, may get the chance to appear as a guest on a popular television show. However, he must demonstrate that he accepts frequent interruptions by the host and competition from a musician who also wants to brand himself. Other interesting points about the mass media are elaborated and discussed in several of the articles in this special issue.

\section{The connection between media and differentiation of society}

Luhmann is very sensitive in regards to the relation between new media and social evolution:

If media and techniques of communication change, if the facilities and sensitivities of expression change, if codes change from oral to written communication, and, above all, if the capacities of reproduction and storage increase, new structures become possible, and eventually necessary, to cope with new complexities. (Luhmann, 1990, p. 100). 
Luhmann suggests a logical, evolution-dependent connection between writing and printing, on the one hand, and symbolically generalised communication media on the other, because they presuppose "writing before they can begin their process of being separated out and also printing before they can be fully developed" (Luhmann, 1999, p. 322). Further, Luhmann (1999, p. 358, 1990, p. 91) sees writing, printing and symbolically generalised communication media as generating the functional differentiation of society.

The print medium makes the production of many identical copies of messages possible and therefore results in a huge increase in complexity, but at the same time provides society with new possibilities for communication. Together these two consequences worked as a catalyst for the emergence of the symbolically generalised communication media. Subsequently, the functional systems were separated out from the old societal hierarchy, introducing a new poly-centred order of society around the functional systems. Electronic media did not seem to alter this form of differentiation totally. Yet, according to Luhmann (1999, p. 411), it is still an open question whether society will change fundamentally with the introduction of the computer, which is what happened with the introduction of writing and printing.

Luhmann (1999, pp. 410-412) proposes that Aristotle's teleological theory was a societal defence mechanism against the meaning surplus brought about by alphabetisation: if it is possible to fix the place of a text through categorisation, it is possible to work with its meaning. In regard to the print medium, Luhmann points at Descartes and the restless self, the reader who walks from one book to the next book, finding that while each one expresses truth, the sheer variety of claims motivates doubt, doubt as a methodological orientation. Now it is the computer that provides society with a surplus of meaning, but in this regard, according to Luhmann, we must wait and see what is going to be condensed as culture, because: "forms of meaning only condense in communication itself" (Luhmann, 1999, p. 411). This is a striking example of how Luhmann as a sociologist does not see technology as determining the social, but as a milieu that provides society with its possibilities and limitations. Yet we must count Luhmann among the great medium theorists, like Innis, McLuhan, Ong, Eisenstein and Meyrowitz; but contrary to them, his medium theory is shaped within a general sociological theory. If on the contrary we compare Luhmann with other great modern social thinkers, such as Foucault, Bourdieu, Habermas or Giddens, it becomes obvious that none of them is as attentive to media as Luhmann. Therefore, if one wants to understand the link between modern society and media, Luhmann's work is not the worst place to look for answers and guidance.

\section{The articles}

We begin with Mikkel Fugl Eskjær's article (in Danish) "From Mass Media to Media System - Code Discussions in Systems Theoretical Media Research", which provides a discussion of Luhmann's theoretical postulate that the mass media has only one code for selecting which communications are part of the system. 
The mass media seen as a functional system is also a main topic of Kjetil Jakobsen's article "Observing the Stars. Love in the Age of Systems", but this article focuses on the subsystem of entertainment and its relation to the code of love in regard to personal identitymaking in a time of globalisation of pop culture and entertainment.

Christian Wymann's article "Tattoo: A Multifaceted Medium of Communication" provides a form/medium discussion about tattoos, in which the author argues that tattoos function as a multifaceted medium of communication.

The mass media system is further explored in Markus Rhomberg's article "Risk Perceptions and Public Debates on Climate Change: A Conceptualisation Based on the Theory of a Functionally-differentiated Society". The focus of this article is on the climate debate and how the political-, scientific- and mass media functional systems are vital aspects in the public debate on this topic.

Daniela Korbas-Magal's article "Risk Communication as an Operation Meant to Produce and Share Audiences" is based on qualitative data collected from in-depth interviews conducted with 22 risk communicators (scientific professionals, spokespeople and journalists) in Israel. The author reports that risk communicators play a major role in defining, creating and producing audiences for the mass communication system.

In Peter Kåhre's article (in Swedish) “Luhmann's Mass Media Theory and Internet as an Artificial Intelligent Semiotic System", it is argued that a modern model of Al-programming called Connectionism in a distributed design can be used to reformulate Luhmann's view on the role of mass media. It is suggested that the Internet and Al-programmed search systems and robots might work as an artificial semiotic system that produces possibilities for second-order observations.

In the first part of the article "Interviewing Media Workers", Heike Graf provides us with a methodological discussion of the interview from a systems theoretical perspective, and in the second part she gives examples of how systems theory can be applied in order to analyse interviews. The examples are from a current study of media workers' experiences with ethnic diversity in newsrooms.

Lars Clausen's article (in Danish) "Media Disruptions between Organisations and Networks" examines the elite's dependence on diffusion media and communication media within the Luhmannian systems theory. The hypothesis is that the specific form of elite has specific, epochal media dependencies, and this is evident in current social science research.

Jesper Tække's article (in Danish) "Facebook - A Network within the Societal Community" addresses the concept of network as its main topic and provides a Luhmannian analysis of network as communication. Facebook is seen as consisting of thousands of parallel networks, and the article discusses how to understand this form of communication and its social and personal implications.

Facebook is also the focus in Daniel B. Lee, Jessica Goede and Rebecca Shryock's article "Clicking for Friendship: Social Network Sites and the Medium of Personhood". The article uses Luhmann's media theory to identify specific differences in how communication 
is organised and reproduced on networking sites. It proposes that the electronic medium appears to be changing the way participants selectively construct and bind expectations of personhood and communicative ties to themselves and others.

\section{References}

Bateson, G. (2000 [1972]). Steps to an ecology of mind. Chicago: The University Press of Chicago Press. Brauns, J. (2002). Die Metaphysik des Mediums. In Brauns, J. (Eds.), Form und Medium (pp. 9-20). Weimar: VDG.

Eisenstein, E. (1983). The Printing Revolution in early Modern Europe. USA: Cambridge University Press.

Esposito, E. (1999). Two-sided forms in language. In Baecker, D. (Ed.), Problems ofform (pp. 78-98). Stanford, California: Stanford University Press.

Foerster, H. v. (1981). Das Konstruieren der Wirklichkeit. In Watzlawick, P (Eds.), Die erfundene Wirklichkeit - Wie wissen wir, was wir zu wissen glauben (pp. 39 - 60). München, Zürich: Piper \& Co.

Habermas, J. (1997 [1981]). Teorien om den kommunikative handlen. Aalborg: Aalborg Universitetsforlag. Heider, F. (1959). On Perception and Event Structure, and the Psychological Environment. Selected Papers by Fritz Heider. New York: International Universities Press Inc.

Krämer, S. (1998). Form als Vollzug oder: Was gewinnen wir mit Niklas Luhmanns Unterscheidung von Medium und Form? Rechtshistorisches Journal 17, 558-574.

Luhmann, N. (1986). Love as Passion: The Codification of Intimacy. UK: Polity Press.

Luhmann, N. (1989 [1986]). Ecological Communication. Cambridge: Polity Press.

Luhmann, N. (1990). Essays on Self-Reference. N.Y.: Columbia University Press.

Luhmann, N. (1992). The Form of Writing. Stanford Literature Review (9),1, 25-42.

Luhmann, N. (1995). Social Systems. Stanford: Stanford University Press.

Luhmann, N. (1999). Die Gesellschaft der Gesellschaft. Frankfurt am Main: Suhrkamp taschenbuch wissenschaft.

Luhmann, N. (2000a). Art as a Social System. Stanford: Stanford University Press.

Luhmann, N. (2000b). The Reality of the Mass Media. Cambridge: Polity Press.

Luhmann, N. (2002a). Einführung in die Systemtheorie. Heidelberg: Carl-Auer-Systeme Verlag.

Luhmann, N. (2002b). Der Erziehungssystem der Gesellschaft. Frankfurt am Main: Suhrkamp.

Maturana, H. R. \& Varela F. (1980). Autopoiesis and cognition: The realization of the living. London: D. Reidel Publishing Company.

McLuhan, M. (1967 [1964]). Mennesket og Medierne. København: Gyldendal.

Meyrowitz, J. (1985). No Sense of Place: The Impact of Electronic Media on Social Behavior. New York: Oxford Uni. Press.

Ong, W. J. (1982). Orality \& Literacy. London: Routledge.

Spencer-Brown, G. (1969). Laws of form. London: George Allen and Unwin Ltd. 
Jesper Takke

Assistant professor, Ph.D.

Department of information and media studies

Aarhus University, Denmark imvjet@hum.au.dk

Michael Paulsen

Associate professor, Ph.D.

Institute of philosophy, education and the study of religions University of Southern Denmark, Denmark paulsen@ifpr.sdu.dk 